\title{
Contrasting effects of climate change on the European and global potential distributions of two Mediterranean helicoid terrestrial gastropods
}

\author{
Małgorzata Proćków ${ }^{1}$ (D) Kamil Konowalik ${ }^{2}$ (D) Jarosław Proćków ${ }^{2}$ (D) \\ Received: 21 January 2019 / Accepted: 4 October 2019 /Published online: 25 November 2019 \\ (C) The Author(s) 2019
}

\begin{abstract}
Predicting the impacts of global climate change on the current and future distribution of alien or endangered species is an essential subject in macroecological studies. Although several investigations have been devoted to animal and plant species, few have addressed terrestrial gastropods. We employed spatial distribution modelling to construct European and global potential distribution ranges of two land snails (Cernuella virgata and Hygromia cinctella) using current and future climate scenarios. Both species have been continuously spreading northward from the Mediterranean region, also being introduced to a few areas outside Europe. We found that under the current climate scenario, most presently occupied areas in Europe are also at high probability of future occurrence of these species. However, under four future climatic conditions, these snails will undergo contrasting scenarios. C. virgata will have a large potential gain, likely due to rising temperatures and its weak fluctuations. In this species, global warming increases in potential area size, accompanied by its morphological and physiological adaptations to arid conditions and the ability to passively disperse, are likely to facilitate invasion into new regions of the world. In contrast, there is no significant change in the geographical distribution of colonisation-prone areas for $H$. cinctella. Our results demonstrate that wetter climatic conditions in the driest season and greater temperature variability will be key limiting factors of its distribution in the future. An understanding of colonisation patterns can help to better manage these invaders and also to formulate policies for their control.
\end{abstract}

Keywords Bioclimatic variables $\cdot$ Emission scenario $\cdot$ Potential distribution $\cdot$ Range shift $\cdot$ Suitable area $\cdot$ Invasive species

Communicated by Wolfgang Cramer

Electronic supplementary material The online version of this article (https://doi.org/10.1007/s10113-019-01573-w) contains supplementary material, which is available to authorized users.

Małgorzata Proćków

malgorzata.prockow@uwr.edu.pl

Kamil Konowalik

kamil.konowalik@upwr.edu.pl

Jarosław Proćków

jaroslaw.prockow@upwr.edu.pl

1 Museum of Natural History, University of Wrocław, Sienkiewicza 21, 50-335 Wrocław, Poland

2 Department of Plant Biology, Institute of Biology, Wrocław University of Environmental and Life Sciences, Kożuchowska 5b, 51-631 Wrocław, Poland

\section{Introduction}

The world is experiencing a period of climate change, which is an important driving force on natural systems (Parmesan and Yohe 2003). Nowadays, significant range shifts toward the poles or toward higher altitudes have been documented for many organisms (Parmesan and Yohe 2003; Root et al. 2003; Lenoir et al. 2008). A large part of these changes may be attributed to increased global temperatures. In Europe, thermophilous terrestrial species with Atlantic or Mediterranean distributions are intensively spreading northwards (Roques et al. 2009; Peltanová et al. 2012a, b). Some of these species are highly invasive and cause damage to the environment, economy, or human health. In particular, species invasions have contributed to the extinction of native species (Clavero and García-Berthou 2005), and the alteration of fire regime, nutrient cycling, and hydrology in native ecosystems (Mack 
et al. 2000). Additionally, they can cause economic losses (Wise et al. 2012), reduce agricultural yield (Follak and Essl 2013), introduce pathogens (Sugui et al. 2012), and result in genetic pollution (Zhan et al. 2012). In this context, a detailed understanding of the effect of climate change on non-native/ exotic/alien species is very important.

Species distribution modelling is a valuable approach for understanding the relationship between the presence of a species and climatic conditions (Gormley et al. 2011). This approach allows for the determination of the relationship between the presence of a target species and the climatic features of the locations they inhabit. The potential geographic distribution of any given species can be obtained by applying the relationship to a wider geographic range. By applying the relationship to different climate scenarios, the projected potential invasion area of a species can be modelled (Xu et al. 2013). Although an increasing number of such studies have been devoted to animal and plant species, only few have addressed terrestrial gastropods (Weaver et al. 2006; Hatteland et al. 2013; Beltramino et al. 2015; Sarma et al. 2015; Sen et al. 2016).

In the present study, two helicoid land snails, namely Cernuella virgata (Da Costa, 1778) and Hygromia cinctella (Draparnaud, 1801), were chosen to investigate the effect of climate change on species colonisation. These originally Mediterranean species were selected because of their widespreading ranges northward in many European countries. At present, $C$. virgata has been known from the UK (first record 1778), France (1849), Italy (1870), the Netherlands (1874), Spain (1880), Portugal (1880), Croatia (1932), Romania (1941), Bulgaria (1975), Germany (1992), Austria (2003), and Italy, Serbia, Greece, Turkey, Ukraine, Russia, Morocco, and Tunisia (Falkner 1990; Lahmar et al. 1990; Gerber 1994; Fischer and Duda 2004; Neubert 2011; Irikov and Gerdzhikov 2013). It has also been introduced to the USA and Australia (Baker 1988, 2002; Michalak 2010). Recently, Chinese ports have intercepted snails in barley, rapeseed, and other consignments from abroad (MOA, AQSIQ 2012).

H. cinctella occurs in France (first record 1801), Spain (1846), France (Corsica, 1855), Italy (1870), Montenegro (1887), Croatia (1932), Hungary (1938), the UK (1950), Austria (1978), Switzerland (1980), Belgium (1994), Germany (1995), and the Netherlands (1995) (Clessin 1887; Páll-Gergely 2011; Neucker van and Scheers 2014). It has also newly arrived in the Czech Republic (2010), Bulgaria (2014) (Říhová and Juřičková 2011; Dedov et al. 2015), and New Zealand (Walton 2017).

Although these two snails live as synanthropes at roadsides and in disturbed environments, they prefer different habitats. C. virgata lives in dry habitats, in sandy dunes and on calcareous substrate, on and under herbal plants, frequently in coastal regions, whereas $H$. cinctella inhabits open areas, among low shrubs and herbs, often at small water currents or in river valleys (Welter-Schultes 2012). Additionally, due to the remarkable adaptability of $C$. virgata, it tolerates cultivation field habitats and has become an invasive species and a serious agricultural pest in some parts of Europe, Australia, the USA, Japan, and Chile (Godan 1983; Baker 2002; Barker 2004; Cowie et al. 2009; Stojnić et al. 2013). Therefore, it became one of the most important quarantined terrestrial molluscs in America and China (USDA 2008; MOA, AQSIQ 2012). Besides being a potential threat to cultivated plants, such as beans, cereal, various fruits, and vegetables, as well as ornamental plants, it also acts as an intermediate host to several parasites that affect humans and domestic animals (López et al. 1998; Georgiev et al. 2003; Butcher and Grove 2006).

In this study, we first predicted the potential distributions of $C$. virgata and $H$. cinctella under current climatic conditions. Then, we modelled the potential distributions of these two species under future climatic conditions (four scenarios) by the year 2070. Correlation between climate change and the invasion mechanism of these two species was studied by comparing different potential distributions under different climatic conditions to identify bioclimatic factors that contribute to the colonisations of $C$. virgata and $H$. cinctella.

\section{Materials and methods}

\section{Distribution data}

For C. virgata and H. cinctella, a total of 305 and 192 records, respectively, were collected from the literature, personal observations, museum collections, and online data. These records were converted into a MS Excel format with specimen location, latitude, longitude, and data source (Online Resource 1).

\section{Environmental data and spatial distribution modelling}

To develop spatial models, 19 bioclimatic variables from the CHELSA version 1.1 database (Karger et al. 2016) were used. Additionally, 18 potentially relevant soil characters were obtained from Global Soil Information Based on Automated Mapping (Hengl et al. 2014; www.soilgrids.org), with a 250$\mathrm{m}^{2}$ resolution and upscaled to match the resolution and extent of the bioclimatic variables ( 30 arc seconds). If different levels were available, only level $0 \mathrm{~cm}$ (topsoil) and $5 \mathrm{~cm}$ were selected, since snails lay their eggs no deeper than 3-4 cm into the ground.

To select an appropriate modelling extent for each species, we followed the procedure proposed by Sobel (2014). Around each locality, we drew circular buffers with the following diameters: $0.025^{\circ}, 0.05^{\circ}, 0.2^{\circ}, 0.5^{\circ}, 0.75^{\circ}, 1^{\circ}, 1.5^{\circ}, 2^{\circ}, 3^{\circ}, 4^{\circ}$, $5^{\circ}$, and $8^{\circ}$. In the next step, these buffers were used to crop all 
available variables, which were then used as an input for spatial distribution modelling. We used the maximum entropy method implemented in Maxent version 3.4.1 (Phillips et al. 2019). The maximum number of iterations was set at $10^{4}$ and the convergence threshold was set at $10^{-5}$. For each run, $20 \%$ of the data were used and set aside as test points. The "random seed" option, which provides a random test partition and background subset for each run, was used. The run was performed as a bootstrap with $10^{3}$ replicates and the output was set to cloglog. Cloglog is a complementary log-log transformation used to produce an estimate of occurrence probability, and it is stated as the most appropriate for Maxent (Phillips et al. 2017). It is easy to conceptualise since the estimated probability of presence lies between 0 and 1 , and it potentially gives higher values to areas that are depicted as relatively highly suitable by other available transformations (logistic, raw, cumulative). To convert continuous grids with a cloglog scale to binary grids, we used equal training sensitivity and specificity thresholds. As a result, we obtained 12 models for each species, which were then evaluated using a local minimum in the predicted size of the potential distribution, omission error, and AUC (area under the curve). Omission error was calculated as a proportion between false negatives (known occurrences treated as unsuitable) and true positives (all occurrences). After choosing the best performing buffer, it was used for subsequent analyses.

To reduce co-linearity and select the most important bioclimatic variables, the dataset was reduced using the $\mathrm{R}$ package "MaxentVariableSelection" (Jueterbock et al. 2016) by applying the following criteria: correlation threshold was set at 0.7 , contribution threshold at 1 , and beta-multiplier was tested in the range of 1 to 5 using 0.25 steps. Beta-multiplier defines how closely the model is fitted to the given presence records. Smaller values result in a more localised prediction and potential overfitting while larger values result in a more spreadout and generalised distribution. When optimal values were selected, we ran Maxent using selected settings and cropped variables. Since these snails are of global importance, results were then extrapolated for the whole world. Finally, to account for the possible spread of snails, we estimated their future distribution using climate projections obtained from Coupled Model Intercomparison Project Phase 5 (CMIPP5). Four "representative concentration pathways" (RCPs: RCP26, $\mathrm{RCP} 45, \mathrm{RCP} 60$, RCP85), which differ in predicted $\mathrm{CO}_{2}$ concentrations (IPCC 2013), were analysed. We only considered the models covering all four representative concentration pathways for the year 2070 (average for 2061-2080). These models were obtained from www.worldclim.org. To reduce the bias caused by the selection of only one specific model, they were averaged and the ensemble map for each variable, in particular RCP, was computed (Konowalik et al. 2017; Konowalik and Kolanowska 2018). It is a simplification that catches the general trend specific for a given RCP scenario while reducing the extremes and uncertainties of particular models. To calculate area, maps were reprojected from WGS84 (EPSG: 4326) to Lambert azimuthal equal area (EPSG: 102017). GIS operations were done in QGis (Quantum GIS Development Team 2016) and R (R Developement Core Team 2017) using packages "raster" (Hijmans 2016), and "rgdal" (Bivand et al. 2016).

\section{Results}

\section{Bioclimatic factors contributing to the distribution of $C$. virgata and $H$. cinctella}

In the case of $C$. virgata, the radius of the optimal buffer size was $3^{\circ}$, which is around $342 \times 10^{3} \mathrm{~km}^{2}$. This selection is based on the local minimum, decreased omission error and a relatively high AUC (Fig. 1). It reflects quite well an average distance between known European localities used for modelling (ca. $305 \mathrm{~km}$ ); thus, it may be considered an appropriate accessible area (M, Barve et al. 2011) for this species. In the case of $H$. cinctella, the best results were reached with buffer $8^{\circ}$, which had the lowest omission error and the highest AUC (Fig. 1). Optionally, there was a local minimum at $4^{\circ}$, but the $8^{\circ}$ buffer offered a more conservative threshold when possible area and omission error were taken into account. This buffer size, which is around $2.5 \times 10^{6} \mathrm{~km}^{2}$, roughly encompasses all of Europe, so higher values were not tested.

According to the "MaxentVariableSelection", the lowest AICc (Akaike information criteria with correction for small sample size) for $C$. virgata was obtained with beta-multiplier 2.0 and the following set of variables (percentage in parentheses denotes variable contribution): mean diurnal range (38.7\%), soil pH (22.7\%), isothermality (10.1\%), temperature seasonality $(10.1 \%)$, mean temperature of coldest quarter (7.7\%), sand content (5.0\%), precipitation of driest month (3.0\%), cation exchange capacity of soil (1.4\%), precipitation seasonality $(1.3 \%)$. The values were ordered according to their contribution shown in the parentheses. The AUC reached 0.89 , indicating a good performance of the model. For $H$. cinctella, the lowest AICc was obtained with beta-multiplier 4.25 and the following set of variables (percentage in parentheses denotes variable contribution): precipitation of driest quarter (41.8\%), temperature seasonality (28.8\%), soil organic carbon content (19.8\%), sand content $(9.6 \%)$. In this case, the AUC reached 0.80 , indicating a fair performance of the model.

\section{Potential distribution and range shifts of $C$. virgata}

Predictive maps for $C$. virgata under current climatic conditions successfully identified areas with a high probability of occurrence (Figs. 2a and 3a). In Europe, 


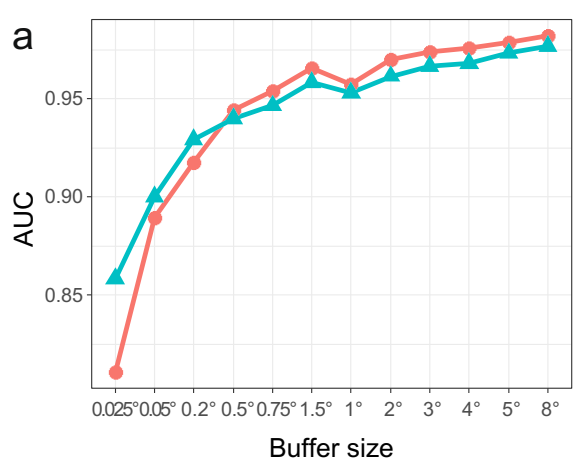

Fig. 1 Graph used to select an appropriate extent for spatial distribution modelling. The $x$-axis contains the 12 tested buffer sizes drawn around observed occurrences. The graphs present the AUC (area under the curve) (a), predicted area (b), and omission error (c). In the case of the AUC, values increase with larger buffers, while the reverse situation is present in omission error (it is partially artificial because more areas are predicted to
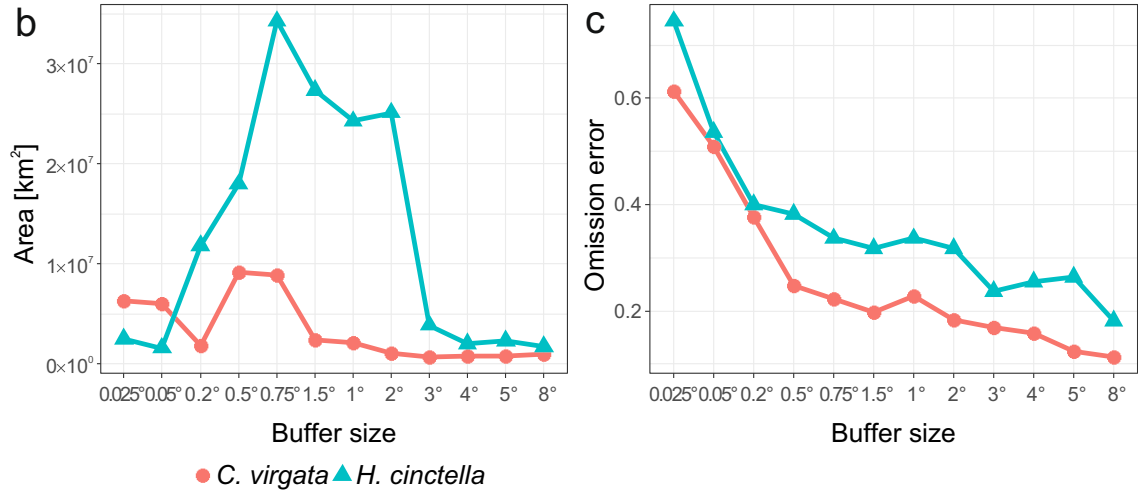

be suitable, which includes more populations, but the model becomes less specific), so predicted area is used as the main criterion where local minimum is expected to give the most appropriate results (Sobel 2014). In the case of $H$. cinctella, the $8^{\circ}$ buffer diameter was selected, and in the case of $C$. virgata, the $3^{\circ}$ diameter was chosen the most suitable regions were located mainly along the Mediterranean coastlines of eastern Spain, France, Italy, western parts of Croatia, and the Greek islands on the Aegean Sea. The Balearic Islands, Corsica, and Sardinia were also highly suitable areas for this invasive snail. Additionally, the coasts of Sicily and Cyprus, as well as the Cap Bon peninsula in Tunisia, had high probabilities of suitable places for $C$. virgata colonisation. Other favourable areas included the Bulgarian, Turkish, and Crimean coastlines along the Black Sea. In Western Europe, regions projected to be highly suitable for $C$. virgata were located along the Atlantic coast of France, extending to Belgium, the Netherlands, and Denmark (including islands on the Baltic Sea). In almost all these areas, present populations have already been established. Outside Europe (Fig. 3a), there are also some potential regions that have a high risk of invasion under the current climate scenario. They comprise, among others, the western Gulf Coastal Plain and southeast Florida in the USA, the coast of the Argentine Sea along Provincia de Buenos Aires and Provincia de Río Negro in Argentina, the Galápagos Islands, and the coastal part of northeast Thailand, southeast China and Taiwan, reaching southern Japan.

Model predictions under different RCP scenarios were variable in their range shift projections (Fig. 4). Future model projections revealed possible changes in the potential distribution of $C$. virgata. Under the four RCP emission scenarios, the ensemble model projected rises in suitability in a proportion of 3-9\% (Table 1) of most European regions, excluding only the northernmost and easternmost parts, as well as the Alps, the Carpathians, and some smaller areas in central Europe (Fig. 2b-e). Some probability shifts were also identified all over the world (Fig. 3b-e). For example, many areas in
Australia, South America, and Asia became susceptible under the RCP26 and RCP85 scenarios. Regions currently unsuitable for $C$. virgata invasion, but projected to become suitable by 2070 (34-54\%), were northward and southward shifts in the area of climatic preference for this snail.

\section{Potential distribution and range shifts of $H$. cinctella}

The presence samples and potential distribution of $H$. cinctella under current climatic conditions are shown in Fig. 5a for Europe and in Fig. 6a for the global projection. The potential and actual distributions are generally similar in Europe and include Great Britain, France, Belgium, the Netherlands, Germany, Italy, and Croatia. A high probability of colonisation exists in areas where the actual and potential distributions are different, covering the Turkish, Georgian, and Crimean coastlines along the Black Sea. Interestingly, there are also some current records that cover regions potentially not suitable for this species. These include the Swiss Alps, Hungary, and Bulgaria (Fig. 5a). Furthermore, a very high potential for colonisation exists in several parts of other continents, like Australia, Asia, both Americas, and Oceania. Highly suitable environs for this snail also include some areas in Africa and South and Central America (Fig. 6a). The area predicted to be suitable for $H$. cinctella reaches around 5.2 million $\mathrm{km}^{2}$.

There were no significant differences between the areas of suitability between present, RCP26, RCP45, RCP60, and RCP85 scenarios in Europe (Pearson's correlation coefficient: $r=0.97-0.98)$. However, there was an increase of $0.4 \%$ in the area with suitability under RCP26, but a decrease of $1.5 \%$ under RCP45, $1.7 \%$ under RCP60, and $3.2 \%$ under RCP85 (Fig. 5b-e and Table 1). Concerning the global projection, similarly, there were no significant 


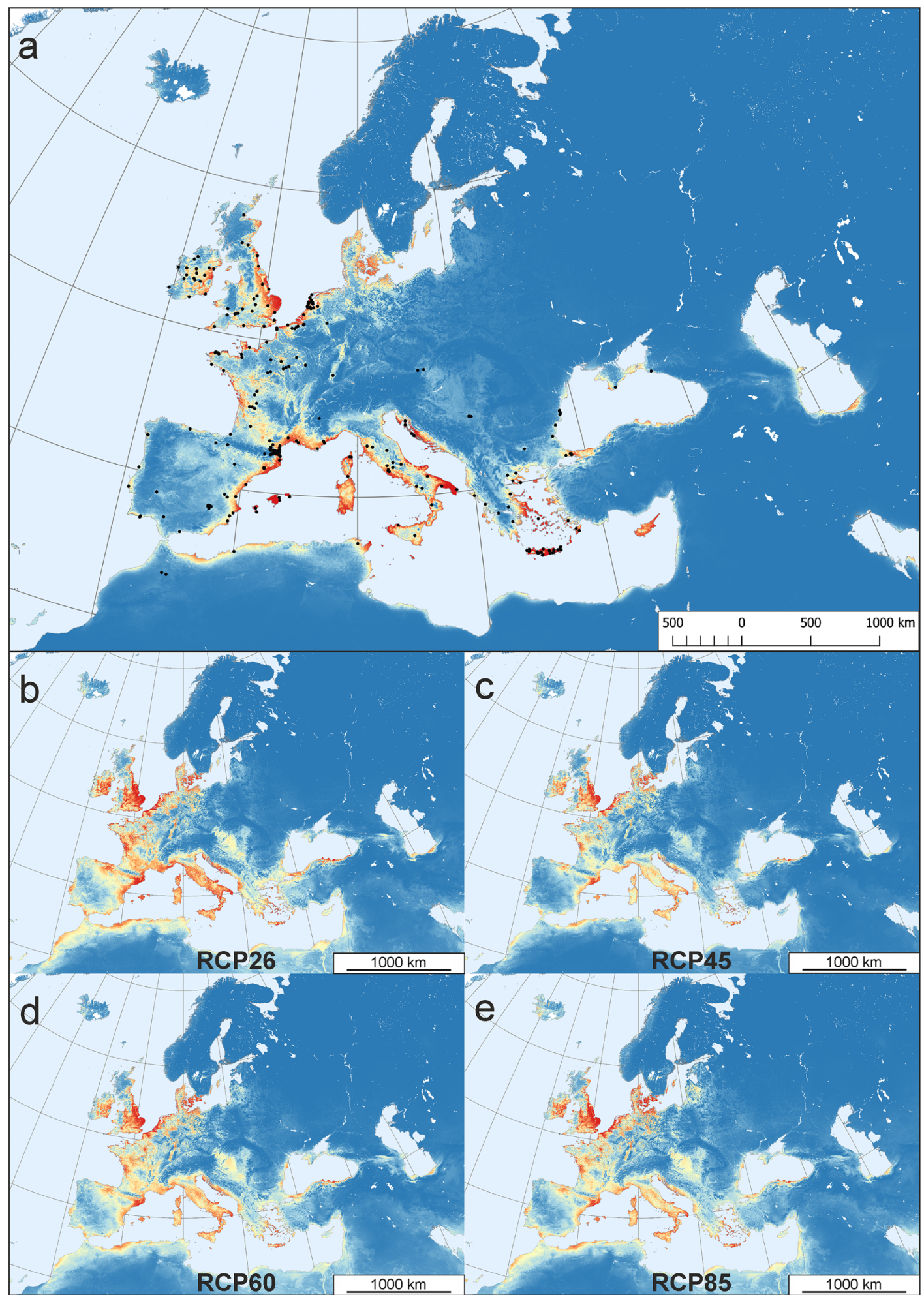

Fig. 2 Potential distribution of C. virgata under a current and four climate change RCP (representative concentration pathway) scenarios: b RCP26, c RCP45, d RCP60, and e RCP85 for Europe. Points indicate the

differences between the areas of suitability between the present and the four future scenarios (Pearson's correlation coefficient: $r=0.96-0.97)$. Regions with consistently very observed occurrences. Blue to red colours indicate unsuitable to highly suitable areas. Meridians and parallels are spaced by $10^{\circ}$. Maps are projected using ETRS 89 (EPSG: 3035)

favourable environments for $H$. cinctella were located mainly in the southeastern states of the USA, large parts of southeast South America, Southeast Asia, and southeast 


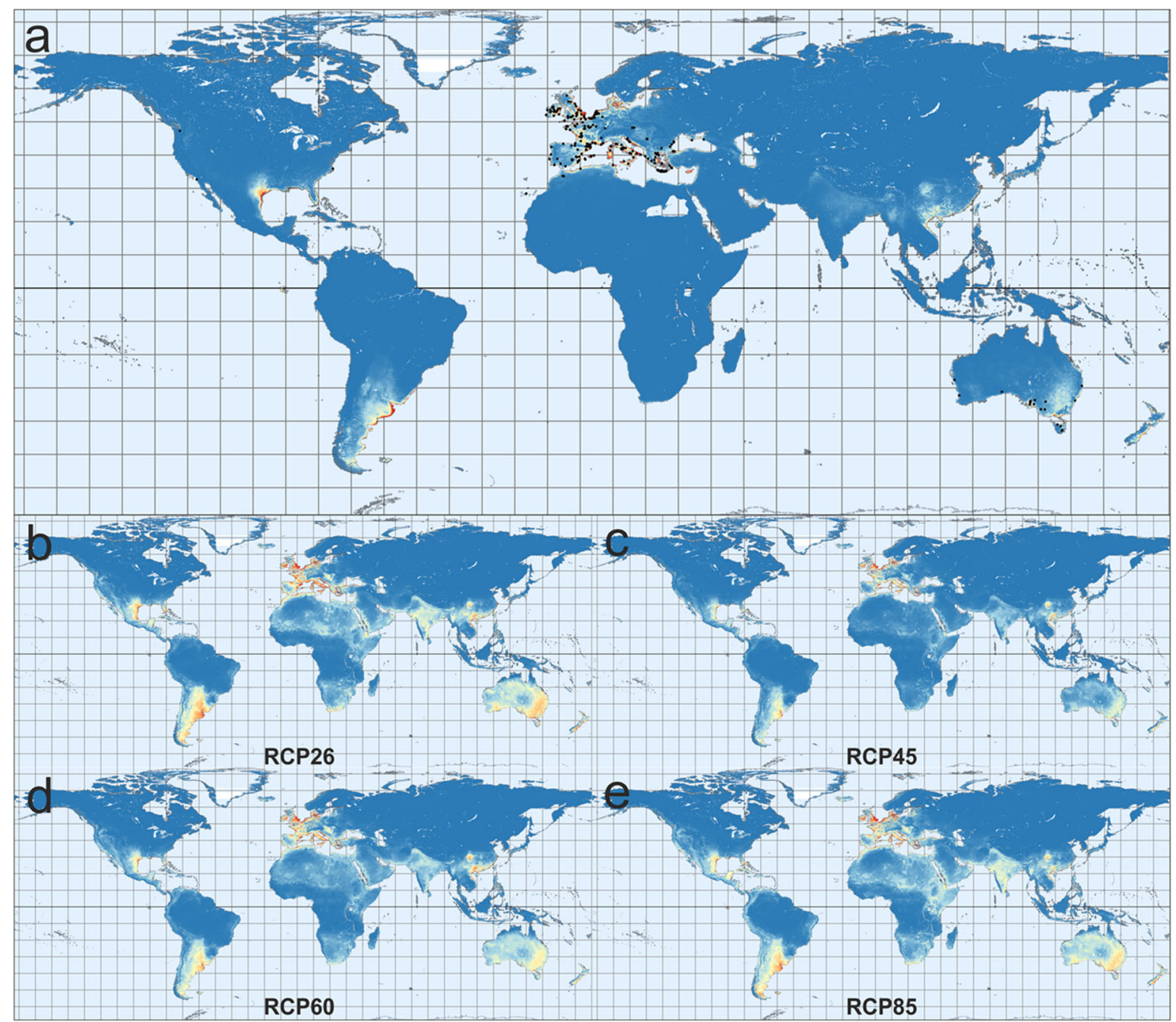

Fig. 3 Global projection of the potential distribution of C. virgata under a current and four climate change RCP (representative concentration pathway) scenarios: b RCP26, c RCP45, d RCP60, and e RCP85.
Points indicate the observed occurrences. Blue to red colours indicate unsuitable to highly suitable areas. Meridians and parallels are spaced by $10^{\circ}$. Maps are projected using WGS 84 (EPSG: 4326)
Australia including New Zealand. Other fairly suitable regions included southern coast of Africa, eastern Madagascar, some parts of Central and South America, and the Pacific Island regions (Fig. 6b-e). The global change of the suitable areas generally increased and varied from 8 to $10 \%$ (Table 1).

\section{Discussion}

Organisms may respond to climate change by adapting to changing environmental conditions, shifting their niche, expanding to newer areas or, in the worst case scenario, becoming extinct if unable to adapt to the changing environment (Holt 1990). In Europe, over the last decades, an increasing number of species have shifted their range northwards from the Mediterranean (Hickling et al. 2005; Parmesan 2006; Rabitsch 2008; Roques etal. 2009; Peltanováetal. 2012a, b). The process of colonisation is visible since the glacial retreat from Central Europe ca. 12,000 years ago, but in recent decades, it has accelerated greatly. Global warming is supposed to be an important driving force behind distributional shifts. However, climate change is not the sole ultimate factor governing or driving range expansions (Gaston 2003). Additional forces, such as habitat change, unintentional human-induced transportation by vehicles and with goods, intentional release for biological control, and natural dispersal, arealso responsible for the successful establishment of many species in new areas (Rabitsch 2008).

In predicting species' distributions in relation to climate change, spatial distribution models can be helpful. In this study, we predicted the potential distribution of two helicoid land snail species (Cernuella virgata and Hygromia cinctella) under current and future climatic conditions. We found that, compared with the relatively suitable current climatic conditions, these two species will undergo contrasting future scenarios: a large potential gain for $C$. virgata vs. a relatively stable potential area for $H$. cinctella (Fig. 4). 
Fig. 4 Bubble chart showing area occupancy of the studied species in different RCPs (representative concentration pathways). While the $y$-axis shows total area in square kilometres, the diameter of the circle is proportional to the percentage of suitable area within a particular continent. It shows that the overall area in square kilometres may be relatively small, but it may constitute a large part of a certain continent (e.g. both species occupy a relatively small area in Oceania, but this accounts for roughly $50 \%$ or more of the total area of the region)

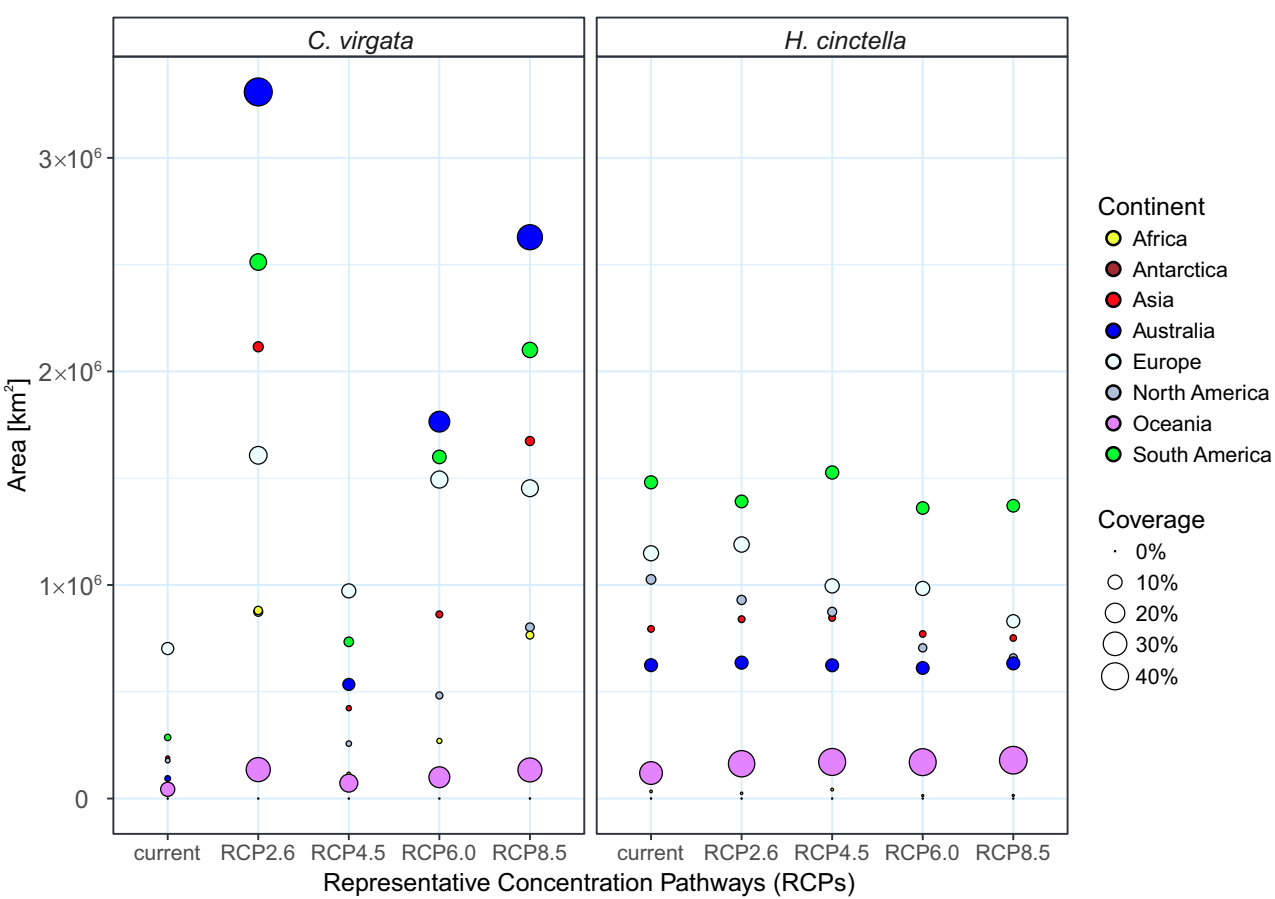

Table 1 Suitable space shown as a percent of the continents' and world's surface area for current climatic conditions and projections onto four climate change RCP (representative concentration pathway) scenarios. Change refers to the difference between current and projected areas (*under RCP85 scenario $13 \mathrm{~km}^{2}$ of Antarctica becomes suitable for C. virgata)

\begin{tabular}{|c|c|c|c|c|c|c|c|c|c|}
\hline Continent & Current (\%) & RCP26 (\%) & Change (\%) & RCP45 (\%) & Change (\%) & RCP60 (\%) & Change (\%) & RCP85 (\%) & Change (\%) \\
\hline \multicolumn{10}{|l|}{ C. virgata } \\
\hline Asia & 0.4 & 4.7 & 4.3 & 0.9 & 0.5 & 1.9 & 1.5 & 3.7 & 3.3 \\
\hline North America & 0.7 & 3.6 & 2.9 & 1.1 & 0.3 & 2.0 & 1.3 & 3.3 & 2.6 \\
\hline Europe & 7.1 & 16.2 & 9.1 & 9.8 & 2.7 & 15.0 & 8.0 & 14.6 & 7.6 \\
\hline Africa & 0.2 & 2.9 & 2.8 & 0.4 & 0.2 & 0.9 & 0.7 & 2.6 & 2.4 \\
\hline South America & 1.6 & 14.2 & 12.6 & 4.1 & 2.5 & 9.0 & 7.4 & 11.9 & 10.2 \\
\hline Oceania & 10.1 & 31.6 & 21.5 & 16.8 & 6.7 & 23.3 & 13.2 & 31.2 & 21.1 \\
\hline Australia & 1.2 & 43.0 & 41.8 & 7.0 & 5.7 & 23.0 & 21.7 & 34.2 & 33.0 \\
\hline Antarctica & 0.0 & 0.0 & 0.0 & 0.0 & 0.0 & 0.0 & 0.0 & $0.0^{*}$ & $0.0^{*}$ \\
\hline Global & 1.1 & 7.8 & 94.9 & 2.1 & 18.7 & 4.5 & 53.8 & 6.5 & 80.1 \\
\hline \multicolumn{10}{|l|}{ H. cinctella } \\
\hline Asia & 1.8 & 1.9 & 0.1 & 1.9 & 0.1 & 1.7 & -0.1 & 1.7 & -0.1 \\
\hline North America & 4.2 & 3.8 & -0.4 & 3.6 & -0.6 & 2.9 & -1.3 & 2.7 & -1.5 \\
\hline Europe & 11.6 & 12.0 & 0.4 & 10.0 & -1.5 & 9.9 & -1.7 & 8.4 & -3.2 \\
\hline Africa & 0.1 & 0.1 & 0.0 & 0.1 & 0.0 & 0.0 & -0.1 & 0.0 & -0.1 \\
\hline South America & 8.4 & 7.9 & -0.5 & 8.6 & 0.3 & 7.7 & -0.7 & 7.7 & -0.6 \\
\hline Oceania & 27.8 & 38.0 & 10.2 & 39.9 & 12.1 & 39.7 & 11.9 & 41.8 & 14.0 \\
\hline Australia & 8.1 & 8.3 & 0.2 & 8.1 & 0.0 & 8.0 & -0.2 & 8.2 & 0.1 \\
\hline Antarctica & 0.0 & 0.0 & 0.0 & 0.0 & 0.0 & 0.0 & 0.0 & 0.0 & 0.0 \\
\hline Global & 3.5 & 3.5 & 9.9 & 3.5 & 10.3 & 3.1 & 7.9 & 3.0 & 8.6 \\
\hline
\end{tabular}




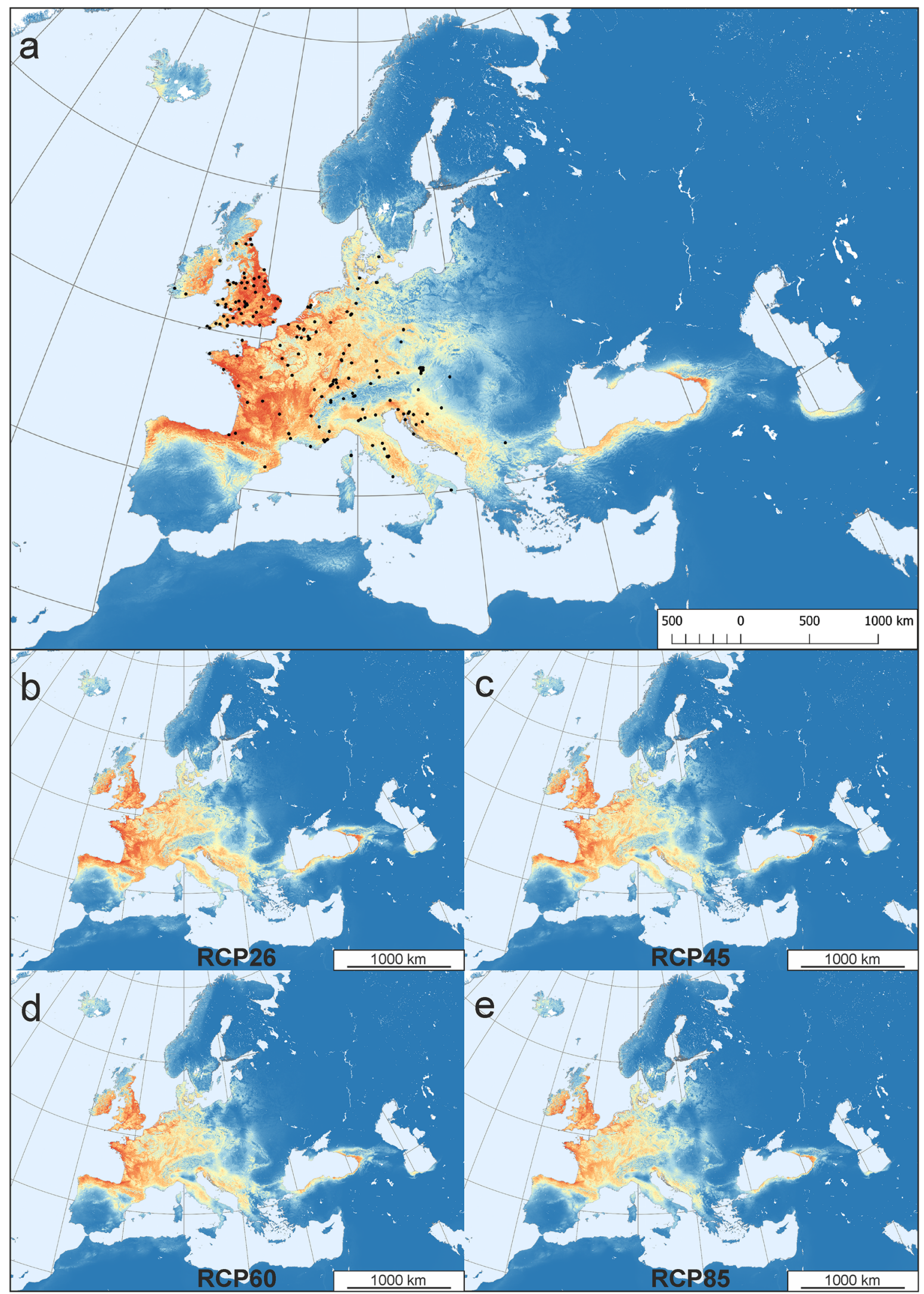

Fig. 5 Potential distribution of $H$. cinctella under a current and four climate change RCP (representative concentration pathway) scenario: $\mathbf{b}$ RCP26, $\mathbf{c}$ RCP45, d RCP60, and e RCP85 for Europe. Points indicate the observed occurrences. Blue to red colours indicate unsuitable to highly suitable areas. Meridians and parallels are spaced by $10^{\circ}$. Maps are projected using ETRS 89 (EPSG: 3035) 


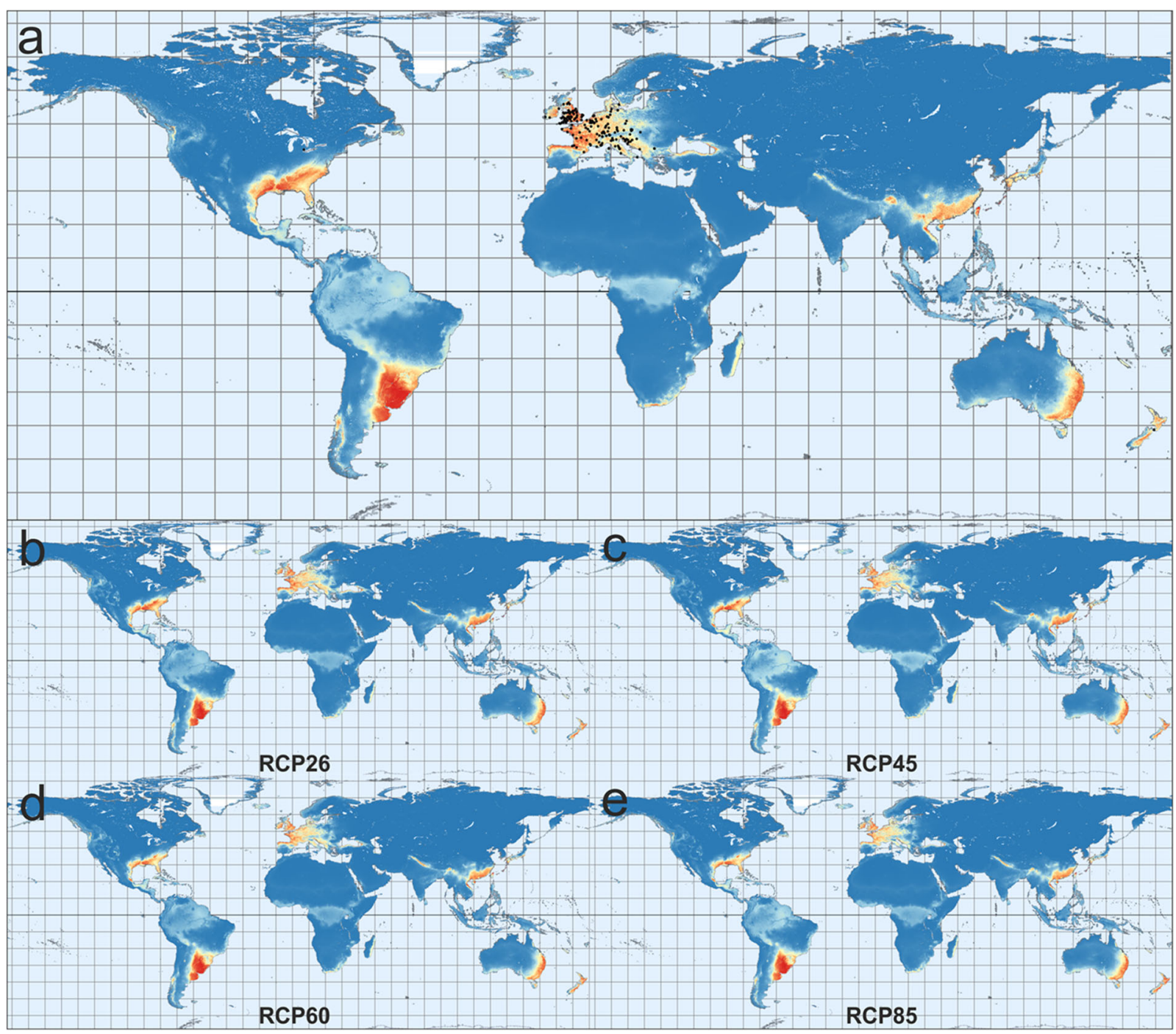

Fig. 6 Global projection of potential distribution of $H$. cinctella under a current and four climate change RCP (representative concentration pathway) scenarios: b RCP26, c RCP45, d RCP60, and e RCP85.
Points indicate the observed occurrences. Blue to red colours indicate unsuitable to highly suitable areas. Meridians and parallels are spaced by $10^{\circ}$. Maps are projected using WGS 84 (EPSG: 4326)

\section{Current spreading pattern and future distribution probability of $C$. virgata and $H$. cinctella}

The actual and potential distribution under current climatic conditions showed that $C$. virgata is frequent in the coastal regions of Europe and several areas of other continents (the coastal part of northeast mainland Southeast Asia, the western Gulf Coastal Plain and southeast Florida, the coast of the Argentine Sea along Provincia de Buenos Aires and Provincia de Río Negro in Argentina, and the Galápagos Islands), where occurrence of this species may be expected (Figs. 2a and 3a). However, under future climatic conditions, its potential distribution range increased considerably and included many areas in Europe (except for its northern and eastern ranges), as well as few areas in Australia, South America, and Asia (Figs. 2b-e and 3b-e). This species has the potential to be widely distributed because of its ability to endure long periods of warmth, dryness, fasting, and light (Schall 2006). Its morphological adaptations, such as white-coloured shells to reflect light and a moderate size of shell aperture to reduce loss of body fluids, are accompanied by physiological adaptations (Dittbrenner et al. 2009). Compared with the similar species Theba pisana, $C$. virgata has shown a significantly higher tolerance to overheating, which results from its greater capability to activate calcium cells in the digestive gland. Also, a greater susceptibility to overheating has been detected in adults than in juveniles, which is associated with high energy losses during reproduction. These features may enable $C$. virgata to be active during long periods of extremely warm and dry weather (Stojnić et al. 2013). This further suggests that global warming resulting from climate 
change is likely to facilitate invasion of $C$. virgata into new regions of the world. Comprehensive analyses based on 72 terrestrial, freshwater, and marine invasive species suggested that the global occurrence of a wide range of invaders is primarily limited by climate. Temperature tolerance was the most important factor and explained on average $42 \%$ of species distributions (Gallardo et al. 2015).

Likewise, our study revealed that temperature-related variables mainly determine the distribution of $C$. virgata to ca. $57 \%$. This indicates that higher temperatures, isothermality, and temperature seasonality were associated with an increased likelihood of the climate being suitable for this snail. Regions with extreme cold and heat were less vulnerable to invasion under current and future climate scenarios. However, temperature alone is insufficient for species distribution modelling, particularly when considering climate change and the associated variations in temperature rise at various regions. $C$. virgata is known to inhabit arid parts of coastal Europe with sandy and limy soils. We proved that soil $\mathrm{pH}$ was the second most important variable for distribution of this snail. Synanthropic populations live at roadsides and along railways and arable lands. Although the snails can stay on harvested land for a long time, they are affected by soil cultivation, upturn, and calcium deficiency and by total lack of plant cover during hot periods (Pomeroy 1968). Moreover, its reproduction seems to be triggered by rainfall and egg laying depends on soil moisture content (Baker 1996; Carne-Cavagnaro et al. 2006).

In contrast to $C$. virgata, the effects of future climate on the predicted range of $H$. cinctella were only slightly discernible (Figs. 4, 5b-e, and 6b-e). Under future scenarios, some invaded or potentially suitable areas were projected to contract as they would no longer encompass suitable climatic conditions. This may be due to changes in precipitation and temperature (precipitation of driest quarter and temperature seasonality explained $71 \%$ of the distribution), which were revealed to be the major factors mostly contributing to the distribution of $H$. cinctella. These findings show that, in the case of this snail, climate change is a key limiting factor to its distribution; thus, this species is not expected to expand much.

In the case of terrestrial gastropods, likewise in other organisms lacking the ability to overcome physical migration barriers, the influence of direct or indirect human-induced spread should also be taken into consideration when interpreting the capacity or extent of invasive species to shift their range in response to climate change. Transport constitutes more than $90 \%$ of the unintentional introductions of alien invertebrate species (Roques et al. 2009). There are many reports of $C$. virgata unintentionally incorporated into shipments of plant materials in international trading, and exported grain shipments have been rejected due to snail contamination (Michalak 2010; Mienis and Vaisman 2010; MOA, AQSIQ 2012). Over a period of 25 years, this snail was discovered in 455 shipments of crops belonging to 21 plant genera originating from 16 countries (Stojnić et al. 2013). Similarly, the human introduction of $H$. cinctella seems to be the most important method of spreading by ship, car, or train transport with plants, soil, or building material (Comfort 1950; Preece 2005; Beckmann and Kobialka 2008; Ř́íhová and Juřičková 2011). It may also actively expand its range along watercourses and railroad tracks. Its spread along rivers was suggested in Germany (Wimmer 2006; Beckmann and Kobialka 2008), and a natural expansion range of $H$. cinctella was believed to take place from the Rhône valley to the north of France (Defossez and Maurin 1995). Moreover, $H$. cinctella eggs are resistant to strongly fluctuating humidity, which could be an indication of the particular robustness of this developmental stage and could facilitate its rapid spread (Wimmer 2006) in the form of eggs in soil or plants, as it was supposed to be particularly prone to dispersal by horticultural activity (Preece 2005).

Generally, the probability of an invasion grows with the intensity of habitat use by humans, which corresponds to the most industrialised regions of Europe, North America, Southeast Asia, and South America (Gallardo et al. 2015). These regions largely coincide with the global hotspots of invasive species richness reported in other studies (Leprieur et al. 2008; Béllard et al. 2013). Our findings also support these conclusions. Under current climatic conditions, we identified regions favouring the occurrence of $H$. cinctella in its native region of the Mediterranean and generally Southern Europe, as well as in Western Europe, where introduced populations already exist. Moreover, areas along the Turkish, Georgian, and Crimean coastlines along the Black Sea appeared to be highly vulnerable to potential colonisation. Although they exhibit suitable climatic conditions for $H$. cinctella, they are not adjacent to established populations. Globally, some regions in southeastern Australia, Asia, and both Americas were also identified as very prone to being colonised under current and future climatic conditions (Fig. 6).

No or only a moderate probability of $H$. cinctella occurrence was predicted for some areas, such as the Swiss Alps, Hungary, and Bulgaria, where populations of this species were previously established. Interestingly, populations from these regions were only recently recorded (Preece 2005; Weddle 2009; Dedov et al. 2015). Although there is some interest in $H$. cinctella as a snail of warm climates, and therefore a possible indicator of climate change, more studies would be required to establish the viability of the species in newly invaded areas, especially to ascertain whether it can overwinter (Weddle 2009). Although it appears vulnerable to frost (Davies 2010), well-established, strong colonies have been observed despite cold winters in Hungary, sometimes with temperatures falling down to $-25{ }^{\circ} \mathrm{C}$ (Wagner 1940), and it has survived both summer and winter conditions in Wellington, New Zealand (Walton 2017). In the Czech Republic, H. cinctella also survived the cold winter. However, in spring, a number of empty shells (many with remnants of a snail body) were found. Some living individuals 
were hiding under planks and bricks, with only a few of them

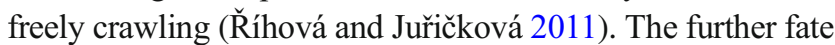
of this population remains unknown. Additionally, in Switzerland, $H$. cinctella was recently recorded to reach sites of much higher altitudes (1020-1400 m a.s.1.) than in almost any other parts of Europe (Dedov et al. 2015).

\section{To be or not to be an invasive species}

It is expected that invasive alien species acting synergistically with climate change might have a much larger impact on the local ecosystem than either species acting alone (Masters and Norgrove 2010). It is well documented that $C$. virgata constitutes a serious problem in southern Australia, as it causes significant economic damage on cereals due to very high population densities; yields are reduced, harvest machinery becomes clogged, and grain becomes polluted. On artificial pastures, cattle are repelled from grazing plants with contaminated slimy deposits (Baker 1996, 2002; Leonard et al. 2003). There do not seem to be many records of this species being a pest outside of Australia; this may be because the populations are controlled by natural enemies (Molet 2014). Long-term monitoring studies in Australia (Baker 2008) aimed to discern relationships between weather and the population dynamics of the snails, and to identify temporal variability in snail abundance as a background to the possible introduction of natural enemies from Europe for biological control. Introductions of natural enemies for $C$. virgata have, however, not yet occurred (Baker 2012).

Considering the fast growth and reproductive habit of C. virgata, its broad ecological tolerance, and its high adaptability, as well as facilitated passive dispersal, it is likely that, with climate change, currently isolated areas of infestation in some regions of the world (e.g., South America with the Galápagos Islands, parts of Southeast Asia and North America) may further expand. Therefore, areas that have high biological diversity should be a focus in order to prevent the introduction of this snail. Effective regulatory strategies focused on limiting humanfacilitated propagation and the movement of this species, as well as close monitoring and preventive approaches, are crucial and have been developed and implemented in some countries. For example, $C$. virgata is on quarantine lists in the USA, Canada, and China (Cowie et al. 2009; MOA, AQSIQ 2012), and shipments contaminated with this species have also been rejected by other countries (Mienis and Vaisman 2010; White-McLean 2011). Therefore, given the presented spatial distribution model data, accompanied by morphological and physiological adaptations of $C$. virgata to arid conditions and its ability to passive dispersal, we may assume that the species constitutes a very high risk to potentially invade many areas where it is now absent.

Besides regions that were very prone to colonisation by $H$. cinctella, some fairly suitable areas were detected, which included southern Africa, eastern Madagascar, and some parts of Central and South America, as well as in Oceania. Out of all these areas, the species was just recently introduced to New Zealand (Walton 2017). Adventive species often exhibit a lagtime prior to expanding their range or becoming a pest (Simberloff and Gibbons 2004; Didham et al. 2007). In New Zealand, several related species with similar ecologies, also of European origin, such as Candidula intersecta and Cochlicella barbara, have become abundant and widespread since their introduction in the late 1800s and in 1983, respectively (Barker 1999). Should H. cinctella become established and eradication efforts not be implemented or fail, the species may well spread to gardens and scrubland through much of New Zealand. While it is impossible to predict any negative effects, it seems likely that it will prove to be neither a crop pest nor a significant threat to native snails or other fauna (Walton 2017), especially given the species' preference for synanthropic, disturbed, or cultivated habitats (Preece 2005; Mienis 2010; Ř́ihová and Juřičková 2011; Neucker van and Scheers 2014; Dedov et al. 2015). However, likewise other gastropod species from more southerly European regions (e.g., C. virgata, A. vulgaris, M. cartusiana, H. lucorum) may benefit from the ruderalisation of open areas and replace sensitive species (Peltanová et al. 2012b). Although only damage to garden plants was reported (Mienis 2010), it is unknown whether the presence of $H$. cinctella has adverse effects on the indigenous fauna and flora in Europe. There is no published literature or observations in the natural range of the species to be a pest to crops; nevertheless, confamilial species are significant crop pests in Australia and further afield (Baker 2002).

Acknowledgements Thanks are due to Uwe Göllnitz and Paul Whitehead for providing some records of $H$. cinctella in Germany and the UK. We would like to thank the reviewers for their valuable comments and suggestions.

Funding information This work was partly supported by the National Science Centre, Poland (Narodowe Centrum Nauki, Poland) under grant number 2016/21/B/NZ8/03022.

Open Access This article is distributed under the terms of the Creative Commons Attribution 4.0 International License (http:// creativecommons.org/licenses/by/4.0/), which permits unrestricted use, distribution, and reproduction in any medium, provided you give appropriate credit to the original author(s) and the source, provide a link to the Creative Commons license, and indicate if changes were made.

\section{References}

Baker GH (1988) The dispersal of Cernuella-Virgata (Mollusca, Helicidae). Aust J Zool 36:513-520. https://doi.org/10.1071/ zo9880513

Baker GH (1996) Population dynamics of the Mediterranean snail, Cernuella virgata, in a pasture-cereal rotation in South Australia. In: Henderson IF (ed) Slug and Snail pests in agriculture. BCPC 
Farnham, British Crop Protection Council (BCPC) Symposium Proceedings. 66:117-124

Baker GH (2002) Helicidae and Hygromiidae as pests in cereal crops and pastures in southern Australia. In: Barker GM (ed) Molluscs as crop pests. CABI Publishing, Wallingford, pp 193-215. https://doi.org/ 10.1079/9780851993201.0193

Baker GH (2008) The population dynamics of the Mediterranean snails, Cernuella virgata, Cochlicella acuta (Hygromiidae) and Theba pisana (Helicidae) in pasture-cereal rotations in South Australia: a 20-year study. Aust J Exp Agric 48:1514-1522. https://doi.org/10. 1071/ea08031

Baker GH (2012) The population dynamics of the Mediterranean snail, Cernuella virgata (da Costa, 1778) (Hygromiidae), in continuouscropping rotations in South Australia. J Molluscan Stud 78:290 296. https://doi.org/10.1093/mollus/eys015

Barker GM (1999) Naturalised terrestrial Stylommatophora (Mollusca: Gastropoda). Fauna New Zeal 38:1-253

Barker GM (2004) Natural enemies of terrestrial molluscs. CABI Publishing, London. https://doi.org/10.1079/9780851993195.0000

Barve N, Barve V, Jiménez-Valverde A, Lira-Noriega A, Sean PM, Peterson AT, Soberón J, Villalobos F (2011) The crucial role of the accessible area in ecological niche modeling and species distribution modeling. Ecol Model 222:1810-1819. https://doi.org/10.1016/j. ecolmodel.2011.02.011

Beckmann K-H, Kobialka H (2008) Hygromia cinctella (Draparnaud, 1801) auf dem Eroberungszug durch Deutschland (Gastropoda: Hygromiidae). Club Conchyl Informationen 39:34-41

Béllard C, Thuiller W, Leroy B, Genovesi P, Bakkenes M, Courchamp F (2013) Will climate change promote future invasions? Glob Chang Biol 19:3740-3748. https://doi.org/10.1111/gcb.12344

Beltramino AA, Vogler RE, Gutiérrez Gregoric DEG, Rumi A (2015) Impact of climate change on the distribution of a giant land snail from South America: predicting future trends for setting conservation priorities on native malacofauna. Clim Chang 131:621-633. https://doi.org/10.1007/s10584-015-1405-3

Bivand R, Keitt T, Rowlingson B, Pebesma E, Sumner M, Hijmans R, Rouault E, Warmerdam F, Ooms J, Rundel C (2016) rgdal: bindings for the Geospatial Data Abstraction Library. R Packag. version 1.25. https://cran.r-project.org/package=rgdal. Accessed 15 Dec 2016

Butcher AR, Grove DI (2006) Seasonal variation in rates of sporocyst and metacercarial infection by Brachylaima cribbi in helicid and hygromiid land snails on the Yorke Peninsula, South Australia. Aust J Zool 53:375-382. https://doi.org/10.1071/ZO05054

Carne-Cavagnaro VL, Keller MA, Baker GH (2006) Soil moisture and soil type influence the breeding behavior of the pest snail Cernuella virgata (da Costa). Appl Soil Ecol 33:235-242. https://doi.org/10. 1016/j.apsoil.2005.10.005

Clavero M, García-Berthou E (2005) Invasive species are a leading cause of animal extinctions. Trends Ecol Evol 20:110. https://doi.org/10. 1016/j.tree.2005.01.003

Clessin S (1887) Beitrag zur Fauna der Binnen-Mollusken Dalmatiens. Malakozool Blätter (Neue Folge) 9:44-65

Comfort A (1950) Hygromia cinctella (Draparnaud) in England. J Conchol 23:99-100

Cowie RH, Dillon RT, Robinson DG, Smith JW (2009) Alien non-marine snails and slugs of priority quarantine importance in the United States: a preliminary risk assessment. Am Malacol Bull 27:113132. https://doi.org/10.4003/006.027.0210

Davies P (2010) Land and freshwater molluscs. In: O'Connor T, Sykes NJ (eds) Extinctions and invasions: a social history of the British fauna. Windgather Press, Oxford, pp 175-180

Dedov IK, Schneppat UE, Glogger FK (2015) Hygromia cinctella (Draparnaud, 1801) (Mollusca: Gastropoda: Hygromiidae), a new snail species for the fauna of Bulgaria. Acta Zool Bulg 67:465-469
Defossez JM, Maurin C (1995) A propos de la repartition de l'helicide Hygromia cinctella (Drap.). Bull la Société des Sci Nat l'Ouest la Fr $17: 44-46$

Didham RK, Tylianakis JM, Gemmell NJ, Rand TA, Ewers RM (2007) Interactive effects of habitat modification and species invasion on native species decline. Trends Ecol Evol 22:489-496. https://doi. org/10.1016/j.tree.2007.07.001

Dittbrenner N, Lazzara R, Köhler H-R, Mazzia C, Capowiez Y, Triebskorn R (2009) Heat tolerance in Mediterranean land snails: histopathology after exposure to different temperature regimes. J Molluscan Stud 75:9-18. https://doi.org/10.1093/mollus/eyn033

Falkner G (1990) Binnenmollusken. In: Fetcher R, Falkner G (eds) Weichtiere. Europäische Meeres- und Binnenmollusken, Steinbachs Naturführer. Mosaik Verlag, München, pp 112-280

Fischer W, Duda M (2004) Beiträge zur Kenntnis der Molluskenfauna Österreichs VII. Cernuella virgata (Da Costa 1778), neu für die Molluskenfauna Wiens, sowie Bemerkungen zur Ausbreitung von Monacha cantiana (Montagu 1803), Cernuella neglecta (Draparnaud 1805). Nachrbl Erste Vorarlb Malak Ges 12:10-14

Follak S, Essl F (2013) Spread dynamics and agricultural impact of Sorghum halepense, an emerging invasive species in Central Europe. Weed Res 53:53-60. https://doi.org/10.1111/j.1365-3180. 2012.00952.x

Gallardo B, Zieritz A, Aldridge DC (2015) The importance of the human footprint in shaping the global distribution of terrestrial, freshwater and marine invaders. PLoS One 10:e125801. https://doi.org/10. 1371/journal.pone. 0125801

Gaston KJ (2003) The structure and dynamics of geographic ranges (Oxford Series in Ecology and Evolution). Oxford University Press, Oxford

Georgiev DM, Kostadinova A, Georgiev BB (2003) Land snails in the transmission of protostrongylids on pastures in Southern Bulgaria: variability of infection levels related to environmental factors. Acta Parasitol 48:208-217. https://doi.org/10.1146/annurev-earth040809-152524

Gerber J (1994) Adventive Landschnecken in Südbaden und benachbarten Gebieten. Mitt bad Landesver Naturkunde u Naturschutz, Neue Folge 16:35-41

Godan D (1983) Pest slugs and snails: biology and control. SpringerVerlag, Berlin. https://doi.org/10.1007/978-3-642-68797-6

Gormley AM, Forsyth DM, Griffioen P, Lindeman M, Ramsey DSL, Scroggie MP, Woodford L (2011) Using presence-only and presence-absence data to estimate the current and potential distributions of established invasive species. J Appl Ecol 48:25-34. https:// doi.org/10.1111/j.1365-2664.2010.01911.x

Hatteland BA, Roth S, Andersen A, Kaasa K, Støa B, Solhøy T (2013) Distribution and spread of the invasive slug Arion vulgaris MoquinTandon in Norway. Fauna Nor 32:13-26. https://doi.org/10.5324/fn. v31i0.1473

Hengl T, De Jesus JM, MacMillan RA, Batjes NH, Heuvelink GBM, Ribeiro E, Samuel-Rosa A, Kempen B, Leenaars JGB, Walsh MG, Gonzalez MR (2014) SoilGrids1 km - global soil information based on automated mapping. PLoS One 9:e105992. https://doi.org/10. 1371/journal.pone.0105992

Hickling R, Roy DB, Hill JK, Thomas CD (2005) A northward shift of range margins in British Odonata. Glob Chang Biol 11:502-506. https://doi.org/10.1111/j.1365-2486.2005.00904.x

Hijmans RJ (2016) Raster: geographic data analysis and modeling. In: R Packag. Version 2.5-8. https://cran.r-project.org/package=raster. Accessed 15 Dec 2016

Holt RD (1990) The microevolutionary consequences of climate change. Trends Ecol Evol 5:311-315. https://doi.org/10.1016/01695347(90)90088-U

IPCC (2013) Climate Change 2013: The Physical Science Basis. Contribution of Working Group I to the Fifth Assessment Report of the Intergovernmental Panel on Climate Change [Stocker TF, Qin 
D, Plattner G-K, Tignor M, Allen SK, Boschung J, Nauels A, Xia Y, Bex V, Midgley PM (eds)]. Cambridge University Press, Cambridge, United Kingdom and New York, NY, USA, pp 1535

Irikov A, Gerdzhikov G (2013) Mollusca (terrestrial and marine Gastropods et Bivalvia) from Morocco. ZooNotes 50:1-5

Jueterbock A, Smolina I, Coyer JA, Hoarau G (2016) The fate of the Arctic seaweed Fucus distichus under climate change: an ecological niche modeling approach. Ecol Evol 6:1712-1724. https://doi.org/ 10.1002/ece3.2001

Karger DN, Conrad O, Böhner J, Kawohl T, Kreft H, Soria-Auza RW, Zimmermann NE, Linder HP, Kessler M (2016) CHELSA: climatologies at high resolution for the earth's land surface areas (Version 1.1). In: World Data Cent. Clim. https://doi.org/10.1594/WDCC/ CHELSA_v1_1

Konowalik K, Kolanowska M (2018) Climatic niche shift and possible future spread of the invasive South African Orchid Disa bracteata in Australia and adjacent areas. PeerJ 6:e6107. https://doi.org/10.7717/ peerj. 6107

Konowalik K, Proćków M, Proćków J (2017) Climatic niche of Selinum alatum (Apiaceae, Selineae), a new invasive plant species in Central Europe and its alterations according to the climate change scenarios: are the European mountains threatened by invasion? PLoS One 12: e0182793+. https://doi.org/10.1371/journal.pone.0182793

Lahmar S, Cabernet J, Cheniti T (1990) Land snails and periods at high risk for protostrongylid infection on a sheep-grazed pasture of Northeast Tunisia. Vet Parasitol 36:105-115. https://doi.org/10. 1016/0304-4017(90)90098-V

Lenoir J, Gégout JC, Marquet PA, de Ruffray P, Brisse H (2008) A significant upward shift in plant species optimum elevation during the 20th century. Science 320:1768-1771. https://doi.org/10.1126/ science. 1156831

Leonard E, Baker GH, Hopkins D (2003) Bash`Em, Burn`Em, Bait‘Em. Integrated snail management in crops and pastures. South Australian Research and Development Institute, Adelaide

Leprieur F, Beauchard O, Blanchet S, Oberdorff T, Brosse S (2008) Fish invasions in the world's river systems: when natural processes are blurred by human activities. PLoS Biol 6:e28. https://doi.org/10. 1371/journal.pbio.0060028

López C, Panadero R, Díez P, Morrondo P (1998) Effect of the infection by Neostrongylus linearis on the survival of the intermediate host Cernuella (Cernuella) virgata. Parasite - J la Soc Fr Parasitol 5:181184. https://doi.org/10.1051/parasite/1998052181

Mack RN, Simberloff D, Lonsdale WM, Evans H, Clout M, Bazzazf FA (2000) Biotic invasions: causes, epidemiology, global consequences, and control. Ecol Appl 10:689-710. https://doi.org/10. 1890/1051-0761(2000)010[0689:BICEGC]2.0.CO;2

Masters G, Norgrove L (2010) Climate change and invasive alien species. CABI Working Paper 1, pp. 30. https://www.cabi.org/Uploads/ $\mathrm{CABI} /$ expertise/invasive-alien-species-working-paper.pdf. Accessed 20 Apr 2017

Michalak PS (2010) New pest response guidelines: temperate terrestrial gastropods. USDA-APHIS, Cooperating State Departments of Agriculture, Emergency and Domestic Programs, Frederick, Maryland. https://www.tsusinvasives.org. Accessed 26 Jan 2018

Mienis HK (2010) Nogmaals Gekielde loofslakken Hygromia cinctella in Purmerend. Spirula 372:30

Mienis HK, Vaisman S (2010) The presence of live specimens of Monacha cartusiana (O.F. Müller, 1774) and Cernuella virgata (Da Costa, 1778) (Mollusca, Gastropoda, Hygromiidae) has prevented the import of 23 tons of apples from France into Israel. MalaCo, Le J électronique la Malacol Cont française 6:268-269

MOA, AQSIQ (2012) The list of quarantine pests of the People's Republic of China of the entry of plants. Beijing, China

Molet T (2014) CPHST pest datasheet for Cernuella spp. USDA-APHISPPQ- CPHST. http://download.ceris.purdue.edu/file/2551. Accessed 26 Jan 2018
Neubert E (2011) Cernuella virgata (errata version published in 2018). In: IUCN Red List Threat. Species. https://www.iucnredlist.org/ species/156816/128438787. Accessed 28 May 2019

Neucker van T, Scheers K (2014) The recent colonisation and rapid spread in Belgium of the alien Girdled Snail Hygromia cinctella (Gastropoda: Hygromiidae). J Conchol 41:779-780

Páll-Gergely B (2011) Hygromia cinctella. In: IUCN Red List Threat. Species. https://www.iucnredlist.org/species/156826/5003834. Accessed 28 May 2019

Parmesan C (2006) Ecological and evolutionary responses to recent climate change. Annu Rev Ecol Evol Syst 37:637-669. https://doi.org/ 10.1146/annurev.ecolsys.37.091305.110100

Parmesan C, Yohe G (2003) A globally coherent fingerprint of climate change impacts across natural systems. Nature 421:37-42. https:// doi.org/10.1038/nature01286

Peltanová A, Dvořák L, Juřičková L (2012a) The spread of non-native Cepaea nemoralis and Monacha cartusiana (Gastropoda: Pulmonata) in the Czech Republic with comments on other land snail immigrants. Biologia (Bratisl) 67:384-389. https://doi.org/10. 2478/s11756-012-0020-2

Peltanová A, Petrusek A, Kment P, Juřičková L (2012b) A fast snail's pace: colonization of Central Europe by Mediterranean gastropods. Biol Invasions 4:759-764. https://doi.org/10.1007/s10530-0110121-9

Phillips SJ, Anderson RP, Dudík M, Schapire RE, Blair ME (2017) Opening the black box: an open-source release of Maxent. Ecography 40:887-893. https://doi.org/10.1111/ecog.03049

Phillips SJ, Dudík M, Schapire RE (2019) Maxent software for modeling species niches and distributions (Version 3.4.1). http:// biodiversityinformatics.amnh.org/open_source/maxent/. Accessed 20 June 2019

Pomeroy DE (1968) Dormancy in the land snail, Helicella virgata (Pulmonata: Helicidae). Aust J Zool 16:857-869. https://doi.org/ 10.1071/ZO9680857

Preece RC (2005) Hygromia cinctella in Ireland. J Conchol 38:604

Quantum GIS Development Team (2016) Quantum GIS geographic information system. Open Source Geospatial Foundation Project. http://qgis.osgeo.org. Accessed 15 Dec 2016

R Developement Core Team (2017) R: a language and environment for statistical computing. language and environment Vienna, Austria. http://www.R-project.org/. Accessed 10 Jan 2017

Rabitsch W (2008) The times they are a-changin': driving forces of recent additions to the Heteroptera fauna of Austria. In: Grozeva S, Simov $\mathrm{N}$ (eds) Advances in Heteroptera Research, Festschrift in Honour of $80^{\text {th }}$ Anniversary of Michail Josifov. PenSoft, Sofia, Moscow, pp 309-326

Ř́hová D, Juřičková L (2011) The girdled snail Hygromia cinctella (Draparnaud, 1801) new to the Czech Republic. Malacol Bohemoslov 10:35-37

Root TL, Price JT, Hall KR, Schneider SH, Rosenzweig C, Pounds JA (2003) Fingerprints of global warming on wild animals and plants. Nature 421:57-60. https://doi.org/10.1038/nature01333

Roques A, Rabitsch W, Rasplus J-Y, Lopez-Vaamonde C, Nentwing W, Kenis M (2009) Alien terrestrial invertebrates of Europe. In: Drake JA (ed) Handbook of alien species in Europe. Springer, New York, pp 63-80. https://doi.org/10.1007/978-1-4020-8280-1_5

Sarma RR, Munsi M, Ananthram AN (2015) Effect of climate change on invasion risk of giant African snail (Achatina fulica Férussac, 1821: Achatinidae) in India. PLoS One 10:e0143724. https://doi.org/10. 1371/journal.pone.0143724

Schall RA (2006) NPAG (New Pest Advisory Group) Data: Cernuella virgata a terrestrial snail. United States Department of Agriculture, Animal and Plant Health Inspection Service

Sen S, Shivaprakash KN, Aravind NA, Ravikanth G, Dayanandan S (2016) Ecological niche modeling for conservation planning of an endemic snail in the verge of becoming a pest in cardamom 
plantations in the Western Ghats biodiversity hotspot. Ecol Evol 6: 6510-6523. https://doi.org/10.1002/ece3.2368

Simberloff D, Gibbons L (2004) Now you see them, now you don't! population crashes of established introduced species. Biol Invasions 6:161-172. https://doi.org/10.1023/B:BINV.0000022133.49752.46

Sobel JM (2014) Ecogeographic Isolation and Speciation in the Genus Mimulus. Am Nat 184:565-579. https://doi.org/10.1086/678235

Stojnić B, Jokić G, Đedović S, Vukša M (2013) Damage caused by white snail Cernuella virgata (Da Costa) to green onion crop. Pestic i fitomedicina / Pestic Phytomedicine 28:247-253. https://oi.org/ 10.2298/PIF1304247S

Sugui JA, Peterson SW, Clark LP, Nardone G, Folio L, Riedlinger G, Zerbe CS, Shea Y, Henderson CM, Zelazny AM, Holland SM, Kwon-Chung KJ (2012) Aspergillus tanneri sp. nov., a new pathogen that causes invasive disease refractory to antifungal therapy. J Clin Microbiol 50: 3309-3317. https://doi.org/10.1128/JCM.01509-12

USDA (2008) Port of Tacoma Cernuella virgata (C. virgata) Eradication Program in Pierce County. Washington. https://www.aphis.usda. gov/plant_health/ea/downloads/tacoma_snails_ea6-30-98.pdf. Accessed 26 Jan 2018

Wagner H (1940) Über das Vorkommen von Hygromia cinctella Drap. in Budapest. Arch Molluskenkd 72:83-84

Walton K (2017) Hygromia cinctella (Draparnaud, 1801) (Mollusca: Gastropoda: Hygromiidae): a new adventive land snail for New Zealand. New Zeal J Zool 44:9-13. https://doi.org/10.1080/ 03014223.2016.1210653

Weaver KF, Anderson T, Guralnick R (2006) Combining phylogenetic and ecological niche modeling approaches to determine distribution and historical biogeography of Black Hills mountain snails (Oreohelicidae). Divers Distrib 12:756-766. https://doi.org/10. $1111 /$ j.1472-4642.2006.00289.x
Weddle R (2009) The girdled snail, Hygromia cinctella (Gastropoda: Pulmonata: Hygromiidae): first Scottish record. Glas Nat 25(2):67. https://www.gnhs.org.uk/gn25_2/girdled-snail_weddle.pdf. Accessed 26 Jan 2018

Welter-Schultes FW (2012) European non-marine molluscs, a guide for species identification. Planet Poster Editions, Göttingen

White-McLean JA (2011) Terrestrial Mollusc Tool. In: USDA-APHISPPQ, Cent. Plant Heal. Sci. Technol. Univ. Florida. http://idtools. org/id/mollusc. Accessed 12 Jul 2013

Wimmer W (2006) Hygromia cinctella (Draparnaud, 1801) auf Gut Sunder, Landkreis Celle, Niedersachsen (Gastropoda: Hygromiidae). Braunschweiger Naturkundliche Schriften 7:671675

Wise RM, van Wilgen BW, Le Maitre DC (2012) Costs, benefits and management options for an invasive alien tree species: the case of mesquite in the Northern Cape, South Africa. J Arid Environ 84:80 90. https://doi.org/10.1016/j.jaridenv.2012.03.001

Xu Z, Feng Z, Yang J, Zheng J, Zhang F (2013) Nowhere to invade: Rumex crispus and Typha latifolia projected to disappear under future climate scenarios. PLoS One 8:e70728. https://doi.org/10.1371/ journal.pone.0070728

Zhan A, Darling JA, Bock DG, Lacoursière-Roussel A, MacIsaac HJ, Cristescu ME (2012) Complex genetic patterns in closely related colonizing invasive species. Ecol Evol 2:1331-1346. https://doi. org/10.1002/ece3.258

Publisher's note Springer Nature remains neutral with regard to jurisdictional claims in published maps and institutional affiliations. 